\title{
The Wife's Act of Refusing to Have an Intimate Husband (Equity, Sociological and Health Study)
}

\author{
Amin Songgirin \\ Universitas Pamulang, Kota Tangerang Selatan, Indonesia \\ dosen01842@unpam.ac.id
}

DOI: $10.29240 /$ alquds.v5i2.2603

Submitted: 2021-03-19| Revised: 2021-08-06 | Accepted: 2021-09-05

\begin{abstract}
This paper discusses the hadith cursing angels against wives who do not want to be invited to bed. In discussing it, the author uses an equality approach, a sociological and health perspective. The purpose of this research is to get answers about how the curse can occur. The problem of the bed is an important problem in the household because such rituals are a form of obedience and fulfillment of the rights of both parties as well as a form of worship. Angels act against a wife who refuses the husband's invitation to bed, even when she is menstruating. On the other hand, the husband also sins if his wife asks to make out, but the husband refuses, even though the reason is busy doing worship. By analyzing the hadith through the perspective of equality, historisociology and health, then on the issue of the bed, the curse does not only apply to the wife, but also to the husband, because of the equality between husband and wife, because in addition to the purpose of physic (Z $\bar{a} h i r$ ) goodness, it is far from that to build inner (bätin) pleasure, namely sakinah, mawaddah wa rahmah. In essence, marriage is worship, so it must be interpreted as jimá' as a form of worship, not as coercion or oppression. "Hunna libāsun lakum, wa antum libāsun labun" "You are clothes for them, so they are clothes for you"
\end{abstract}

Keyword: Equality study; Sociological study; Health study; Sexual violence; Sexual relation

\section{Introduction}

Human nature to preserve its existence by way of marriage. ${ }^{1}$ In the language of marriage is "az-₹awaj" which means marriage or "al-wat' $u$ " means

${ }^{1}$ Q.S. ar-Rūm [30]: 21: “And among the signs of His power, He created for you wives of your own kind, so that you might be inclined and at ease with them, and made Him among you a sense of love and affection. Indeed in that there are really signs for people who think". 
intercourse. ${ }^{2}$ In the dictionary of al-Mubit, marriage is "ad-dam" wa "at-tadäkbul" means joining and inserting each other. ${ }^{3}$ Marriage according to the views of the

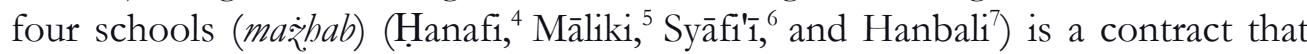
brings the ability (for a man to have sex with a woman) with (beginning in the contract) lafaz of marriage or marriage, or a meaning equivalent to the two words referred to. ${ }^{8}$ Therefore, humans are given a biological need in the form of sexual intercourse, because naturally humans are equipped with sexual tendencies (sexuality libido). ${ }^{9}$

Marriage is mis̄äqan galizan, a very strong commitment to obey Allah's commands and carry it out is worship. ${ }^{10}$ A physical and mental bond between a man and a woman as husband and wife with the aim of forming a happy and eternal family (household) based on the One Godhead. ${ }^{11}$

Thus, getting married is a religious command, part of the Sunnah of the Prophet Muhammad SAW. ${ }^{12}$ To the point that a single life is forbidden. Ibn 1461.

${ }^{2}$ Ahmad Warson Munawwir, Kamus Al-Munawnir, (Surabaya: Pustaka Progressif, 1997), p.

${ }^{3}$ Majduddīn Muhammad Ya'qūb al-Fairūzābādī (Died in 817 AH.), al-Mubiț, (Beirut: Muassasah ar-Risālah, 2005), p. 502.

${ }^{4}$ Full name: Abu Hanīfah Al-Nu'mān Ibn Sābit Ibn Zuṭā Al-Kufi, born in Iraq in 80 $\mathrm{AH} / 699 \mathrm{AD}$ and died in Bagdad Iraq 150 AH./767 AD.

5 The full name 'Abdillāh Ibn Anas al-Aṣbahạni, was born in Medina in 93 AH and died in $179 \mathrm{AH}$.

${ }^{6}$ Full name Abu 'Abdullah Muhammad Ibn Idrīs As-Syāfi' 1 Al Muțālibi Al Quraisyi, born in Gaza in $150 \mathrm{AH}$, died in Egypt in $204 \mathrm{AH}$.

${ }^{7}$ Full name Abu 'Abdillah Aḥmad Ibn Ḥanbāl Hilalusy Syaibāni, born in Baghdad in 163 $\mathrm{AH}$, died in $241 \mathrm{AH}$ in Baghdad.

8 Abdurraḥman al-Jaziri, al-Fiqh 'alā Mazăhib al-Arba'ah, (Beirut: Dār al-Fikr, 1986), Jilid IV, p. 212.

${ }^{9}$ Rahmat Hakim, Hukum Perkawinan Islam, (Bandung: Pustaka Setia, 2000), Cet. Ke-III, p. 15.

${ }^{10}$ Direktorat Pembinaan Peradilan Agama Islam Ditjen Pembinaan Kelembagaan Islam Departemen Agama, 2001, Kompilasi Hukum Islam (KHI), Buku I Hukum Perkawinan, Bab II (Dasar-Dasar Perkawinan), Pasal 2, p. 1. See Atania Rasavena, Seni Bercinta, Pnduan Bercinta ala Melayu Islam, (Yogyakarta: Sophiebooks, 2003), p. 18.

11 UU. R.I. Nomor 1 Tahun 1974, Tentang Perkawinan, Bab I, Dasar Perkawinan, p. 1

${ }^{12}$ From Anas Ibn Mālik R.A. indeed Rasulullah SAW. Praise and praise Allah SWT, then say: "But I pray and sleep, I fast and break, I also marry a woman. Who hates my sunnah, not even from me." (H.R. Muttafaq 'Alaih). Al-Hāfiz Aḥmad Ibn 'Alī Ibn Hajar al-'Asqalānī (773-852 AH.), Bulūgu alMarām min Adillati al-Abkàm: Kitāb an-Nikeăh, (Makkah: Dāru al-Qabbas, 2014), Cet. Ke-1, p. 374. 
'Abbās ${ }^{13}$ once said to Sa'īd Ibn Jubair: ${ }^{14}$ "Get married! Indeed, the best of these people are those with many women (wives)". ${ }^{15}$

Therefore, the wife is a mandate, so it needs to be maintained and treated properly. Because the way to take it is through a religious procession in the marriage contract. As the hadith of the Prophet narrated from Ibn Abbās, as quoted by 'Amir Syarifuddin in his book: "Verily you take it as a mandate of Allah and you mix it with sentences and methods that have been determined by Allab". ${ }^{16}$

In a marriage or in a household, because the rights and obligations between husband and wife have been tied to each other so that "sakinah" will be achieved. From this atmosphere will emerge a sense of love and cherish (almawaddah), so that the sense of responsibility of both parties is higher. From both of them will emerge "ar-rahmah", namely the healthy and blessed offspring of Allah SWT, as well as an outpouring of the love and love of husband and wife and their children. ${ }^{17}$

In maintaining domestic harmony, a husband and wife must carry out their respective obligations. One of them is the bad relationship. Q.S. an-Nisā [4]: 19, meaning: "And treat them (your wives) well". According to an-Nawāwī alBantanī, ${ }^{18}$ what is meant is a fair association. Good in a division of turns (if it happens to be polygamous), giving shopping, and behaving in both words and actions. ${ }^{19}$ Because indeed between marriages regenerate offspring, keep adultery away, foster love in the family, carry out the Sunnah of the Prophet, and channel sexual desire. ${ }^{20}$

13 'Abdullah Ibn Abbas bin 'Abdul Mutțālib bin Hasyim was born in Makkah three years before hijrah, died in Thaif $68 \mathrm{AH}$.

${ }^{14}$ Sa'id bin Jubair al-Asadi al-Kufi, born $38 \mathrm{H}$. in Kufah died in $95 \mathrm{AH}$.

${ }^{15}$ Muhammad Ibn Muhammad Mușțafā al-Iskandarī, Masäil fì az-Zawāj wa al-ḥaml wa alWilädah, (Beirut: Dār Ibnu Hazm, 2002), p. 16.

${ }_{16}$ Amir Syarifuddin, Hukum Perkawinan Islam di Indonesia: Antara Fiqh Munäkahät dan Undang-undang Perkawinan, (Jakarta: Kencana, 2006), p. 41.

${ }_{17} \mathrm{Abu}$ 'Abdillah Muhammad Ibn Ahmad al-Anșāin̄ al- Qurtubī, al-Jāmi’u li Abkeàm alQur'ān, Juz XIV. (Kairo: Dār al-Kātib al-‘Arabī, 1967), p. 16-17.

${ }_{18}^{18}$ Died in 1879 AD./1324 AH.

19 Abu 'Abdul Mu'țī Muhammad Ibn 'Umar Ibn Arbi bin 'Alī al-Tanara Al-Jawi AlBantan̄̄, Syarbu 'Uqūdu al-Lujjaini fì Bayāni Huqūq az-Zaujaini, (bil-Ma'nā 'alā Pesantren), (t.p. t.t.), p. 3 .

${ }^{20}$ Kamal Mukhtar, Asas-Asas Hukum Islam tentang Perkawinan, (Jakarta: Bulan Bintang, 1993), Cet. Ke-III, p. 12-15. 
It is the duty of the wife when her husband invites jim $\bar{a}^{\prime}$ to fulfill her desires naturally. If you do not fulfill it, then that is part of neglecting his duties. The question will arise, is each rejection a sin? How does syara 'view this issue?

Approximately 25-27 April in Pondok Jambu, Cirebon, West Java, a Religious Meeting of the Indonesian Women's Ulema Congress (KUPI) is held. The result confirmed that the law of sexual violence, both outside and inside of marriage, is haram. This violence can be interpreted as "rape". Forms of sexual violence against a wife include forced intercourse according to the husband's taste, for example, a wife is forced to have anal sex, oral sex, or force inserts an object into the wife's vagina, forced intercourse while the wife is asleep or menstruating, as well as verbal and physical intimidation in the context of coercing sexual relations. ${ }^{21}$

For this reason, in this paper, the author will try to parse the hadith related to "Angel's Act for a wife who refuses her husband, when invited to bed". What if the husband is reluctant to have sex but refuses? Is it true, only the wife gets cursed, while on the other hand the husband does not. Under the pretext of this hadith, many men (husbands) are of the view that they are "the most entitled" and ignore their wives. To get this answer, in analyzing the hadith, apart from looking at the interpretation of hadith and the fiqh approach, we also use an equality, social and health approach.

\section{Discussion}

In this study, the purpose of this study was to obtain answers related to the hadith which states that the wife will be cursed by the Angel, if she refuses her husband's invitation to have sex. So that this hadith is used as an excuse for the husband to do as he pleases, regardless of the wife's condition. Often, wives who are reluctant to fulfill their husbands' wishes are considered disobedient, disobedient and misbehaved. Therefore, in the discussion, the hadith related to this theme will be analyzed for the quality of sanad and matan and associated with equality, social and health approaches.

\section{The Hadith Indictment for Wives Rejecting Husband's Invitation to Bed}

A wife who disobeys her husband (refuses) to have sexual intercourse will be cursed by an angel.

\footnotetext{
${ }^{21}$ theconversation.com/larangan-islam-atas-pemerkosaan-dalam-perkawinan-79232
} 


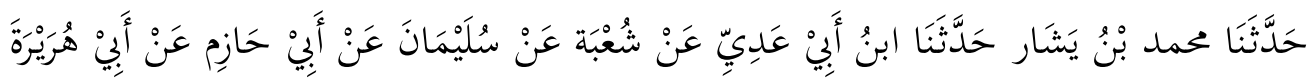

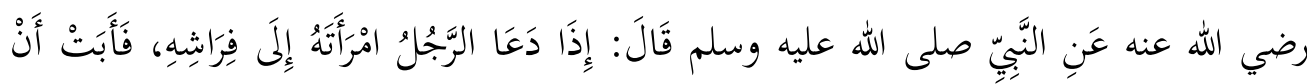

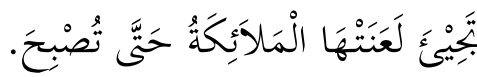

Having told us Mubammad Ibn Basyār, had told us Ibn Abi' Adiyyi from Syu'bah from Sulaimān from $A b i \mathrm{H}$ äzim from Abi Hurairah $\mathrm{R} A$. from Rasulullah $S A W$. Saying; "When the husband takes his wife to bed and the wife is reluctant, the husband is angry at night, the angel curses the wife until dawn", 22

In the Riyādu aṣ-Ṣālihīn book: ${ }^{23}$

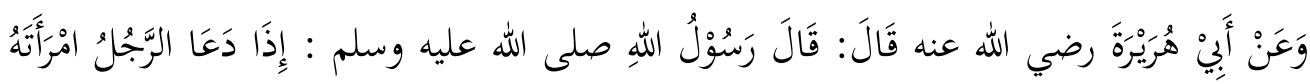

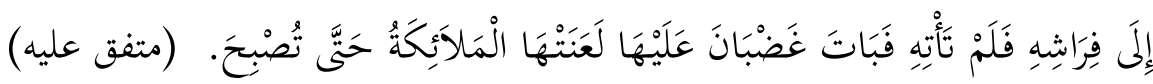

"When the husband invites his wife to bis sleeping place and does not fulfill it, then the busband gets angry (all night) at him, the angel cursed him until dawn." (Muttafaq'Alaib).

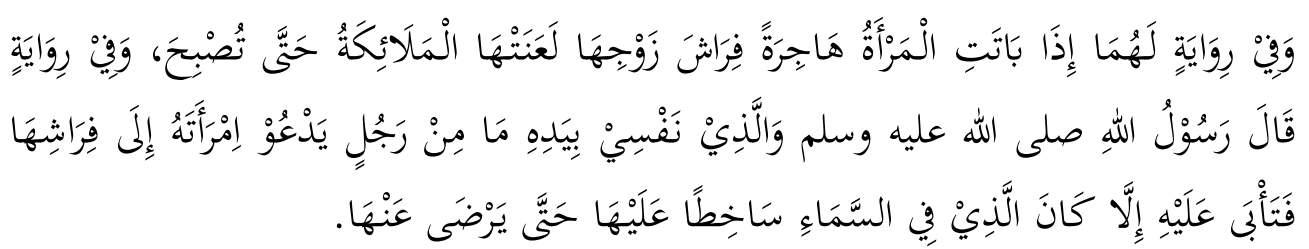

in the history of both; "If a woman sleeps leaving her husband's bed (ie not accompanying her busband) then an angel will curse her until the morning." In one narration explained, Rasulullah SAW. Said: "For the sake of my soul that is in His grasp, a man who invites bed, then his wife refuses the invitation, the people of heaven are angry until her husband forgives. (Muttafaq 'alaib).

This hadith confirms the obligation of a wife to fulfill her husband's biological needs, wherever and whenever, however busy they are. ${ }^{24}$ One of the rights of husbands from wives is to fulfill their sexual needs. ${ }^{25}$

22 Abī 'Abdillāh Muhammad Ibn Ismā’îl al-Bukhārī (194-256 H.), Șab̄̄hu al-Bukhārì, Kitāb an-Nikāh, Hadis No. 5193, (Damsyiq Beirut: Dāru Ibnu Kas̀īr, 2002), p. 1324.

${ }^{23}$ Maḥyuddīn Abī Zakariyā Yaḥyā Ibn Syaraf an-Nawāwī, Riyādu aș-Ṣalibìn min Kalāmi Sayyidi al-Musrsalīn, (Jakarta: Dār Ihyāi al-Kutub al-‘Arabiyyah Indonesia, t.t.), p. 152.

${ }^{24}$ Muhammad Abdullah Nipan, Membahagiakan Suami Sejak. Malam Pertama, (Yogyakarta: Mitra Pustaka, 2000), p. 261.

25 As-Sayyid Mayai, 50 Wasiat Rasulullab SAW Bagi Wanita, (Jakarta: Pustaka al-Kautsar, 1999), p. 70. 
From Ibn 'Umar said, "A woman came to Rasulullah SAW asking; "O Messenger of Allah, what is the right of a husband over his wife? Prophet Muhammad SAW. answered, "the wife may not refuse her husband's invitation even though he is on the back of a camel".

\section{Quality of Hadith in Kitāb Șậh ị̆ al-Bukhātī}

Judging from the muttasil as-sanad, the conveyor siqah, without defects or 'illat, and not awkward syaz, then the quality of sanad is sabì lizatitibi. Between the narrators in the sanad are connected from Imām al-Bukhārī, Muhammad Ibn Basyār, Ibn Abī 'Adiyyi, Syu'bah, al-A'Masy, Abī Hāzim, Abī Hurairah and up to Rasulullah SAW. There are several traditions reported by mubaddis, with the same lafąं's, not contradicting each other. So this hadith is classified as an ähäd hadith and in terms of its majesty, it is maqbül (acceptable).

By looking at the reference source of this hadith, the majority of scholars state that this hadith narrated by Abu Hurairah is sabih. At least in sanad criticism, he has been deemed worthy, true and valid șabỉ Ibn Hajar al-'Asqalānī, ${ }^{26}$ in the book Fath al-Bārî fully supports the validity of this hadith. For him, there are several other traditions that strengthen (syawähid) the above hadith. Namely: the history of Imām Muslim from Abi Hāzim: "By the Essence that controls me, someone who calls his wife to his bed (having sex), then the wife refuses, really everyone in the sky curses the wife until the husband forgives her". ${ }^{27}$

\section{Analysis of the Meaning of Hadith}

In the hadith, the choice of the word is "da' $a$ /L" with the masdar/adverb "da'wahahole which means inviting/inviting in a subtle, polite, kind and wise manner as found in the al-Qur'ān. ${ }^{28}$ Furthermore, the word "firäsy/فراش" bed, according to Ibn Abi Hamzah, as an expression of jima' (bed). If the wife refuses, without aging it will result in the husband's anger being born, then that's when the angel is cursed. Because the form of obedience is absolute, as long as the commandment is in goodness, not immorality. Even in a state of menstruation, it does not mean old age, in terms of having fun "istimta" other than in farj, the way out of blood, a husband has the right to enjoy it. ${ }^{29}$

26 Wafat tahun $852 \mathrm{H}$.

${ }^{27}$ Ibn Hajar al-'Asqalānī, Fath al-Bārì bi sharh șahīh al-Bukhārì, editor al-'Azīs ibn 'Abdullāh ibn Bāz dan Muhammad Fu'ād 'Abd al-Bāqī, juz 25 (Jakarta: Pustaka Azzam, 2008), p. 659.

${ }^{28}$ Tim Penyusun MKD IAIN Sunan Ampel Surabaya, Studi Hadis,, (Surabaya: IAIN Sunan Ampel, 2012), p. 125.

${ }^{29}$ Abu Abdirrahman, 'Aun al-Ma'būd 'alā Syarh Sunan Abì Dawūd, (Beirut: Dār Ibnu Hazm, 2005), p. 1006. 
If the wife refuses to use the sentence "abat/بت" (reluctant) it is associated with the Word of Allah Q.S. al-Baqarah [2]: 34. When Satan refused to prostrate

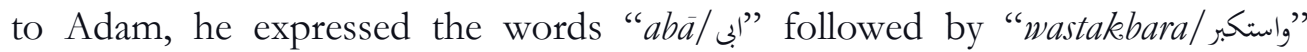
refusing with full rejection (arrogance/reluctance). Then in the hadith, the effect of his wife's refusal is "فبات غضبان عليها"30

As for the curse of the Angel "لعنتها الملائكة" which is inflicted on the wife who refuses the husband's invitation, is the prayer of the Angel of accident for the perpetrator of disobedience as long as in his immorality. Mafhüm mukhälafah is acting like this, as long as he is in obedience the angel will wish him good luck. ${ }^{31}$

The above hadith is sahih. A wife's refusal to fulfill her husband's sexual desires is unacceptable if there is no clear reason, resulting in the husband's disappointment. However, in a wife's physical or psychological condition it is not possible to have sexual intercourse, either because of illness, fatigue, or severe stress, then it feels unfair if the husband forces his will.

Angels as mentioned in the Hadith text can be interpreted as torture and an uncomfortable atmosphere for the wife because she cannot fulfill her husband's sexual needs or because he is scolded by her husband. Rejection also resulted in a disharmonious atmosphere and disrupted communication, which created a tense atmosphere between the two. Therefore, the existence of "cursing" is limited to "dawn". Because when it is dawn, the husband and wife will pray together and forgive each other, so that the husband and wife relationship becomes harmonious again. This hadith also teaches a married couple that the anger or disharmony that occurs between the two must not exceed dawn or it should not be for a long time because it will cause both of them to suffer. ${ }^{32}$

\section{Analysis of the "Matan" Mind} can be drawn:

If you look at the contents of the hadith in question, several conclusions

1. Does not conflict with the reason (although) over time, the issue of gender equality arises;

2. It does not contradict Islamic law, because marriage is a part of worship, so what is good in marriage is worship, including jima';

\footnotetext{
${ }^{30}$ Abu Abdirraḥmān, 'Aun al-Ma 'būd 'alā Syarh Sunan Abì Dāwñ̀d, (Beirut: Dār Ibnu Hazm, 2005), p. 1006.

${ }^{31}$ Ibn Hajar al-Asqalānī, Fathu al-Bāri, Jilid 25, (Jakarta: Pustaka Azzam, 2007), p. 54.

32 Umi Khusnul Khatimah, Hubungan Seksual Suami Istri Dalam Perspektif Gender dan bukum Islam, Jurnal Ahkam: Vol. XII, No. 2, juli 2013, p. 238.
} 
3. It does not contradict the Qur'an, there is an agreement with the Q.S. alBaqarah [2]: 223;

"Your wives are (like) the land where you grow your crops, so come the land where you are cultivating, however, you want." and do (good deeds) for yourself, and fear Allah and know that you will find Him. and give good news to those who believe".

Q.S. an-Nisa' [4]: 19: "..... And get along with them properly ....."

This verse came down to answer the jäbiliyyah tradition which considers women as assets that can be inherited. If the husband dies, then the husband's heirs (who are strong) can control it by being married, married to someone else or even not married until he dies. So the command of the Qur'an to do good through words and deeds, including being patient. As Q.S. al-Baqarah [2]: 228 explains about equality in the household "Wives have the same rights as the obligations imposed on them properly." As exemplified by Rasulullah SAW towards his wives, namely showing happiness, playing with his wives, loving and being gentle, making a living, joking and other good deeds. ${ }^{33}$

\section{Husband's Rights and Obligations}

Marriage is a covenant between men and women to navigate the household ark. Since the contract was executed, at that time the two of them were bound to automatically have mutual rights and obligations that had not previously been owned. ${ }^{34}$

In simple terms, rights are what is received in this case from the partner. The obligation is something that must be carried out for his partner. Obligations are born because there are rights inherent in legal subjects. ${ }^{35}$ Thus, the wife's right is the husband's obligation, on the other hand, the wife's obligation is part of the husband's right. ${ }^{36}$

If a marriage contract occurs (marriage agreement), then a man who becomes the husband has various rights in the family, likewise, a woman who becomes a wife in a marriage has various rights as well. Besides, they also bear the obligations as a result of binding themselves in that marriage. ${ }^{37}$

${ }^{33}$ Ismā‘îl Ibn 'Umar Ibn Kas̀īr al-Dimasyqī, Tafsìru Qur'àni al-'Ażìm, Juz II, (ttp. Dār Țaibah, 1999), p. 242.

${ }_{34}$ Beni Ahmad Saebani, Fiqh Munäkahät 2, (Bandung: CV Pustaka Setia, 2010), hlm. 11.

35 Amir Syarifuddin, Hukum Perkawinan Islam di Indonesia, (Jakarta: Prenada Media, 2007), p. 159.

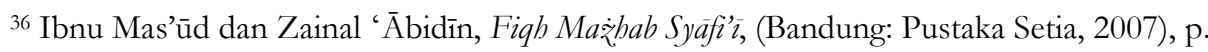
313.

${ }^{37}$ Moh. Idris Ramulyo, Hukum perkawinan Islam, (Jakarta: Sinar Grafika Offset, 1999), p. 63. 
There are two rights related to the obligations and rights of husband and wife, namely material obligations and immaterial obligations. The material in nature means zahir obligations, namely property, including dowry and living. Meanwhile, obligations are immaterial in the form of a husband's inner obligation to his wife, such as leading his wife and children, getting along with his wife in a good way. ${ }^{38}$

Described in Q.S. an-Nisa' [4]: 19, regarding the obligations and rights of a household:

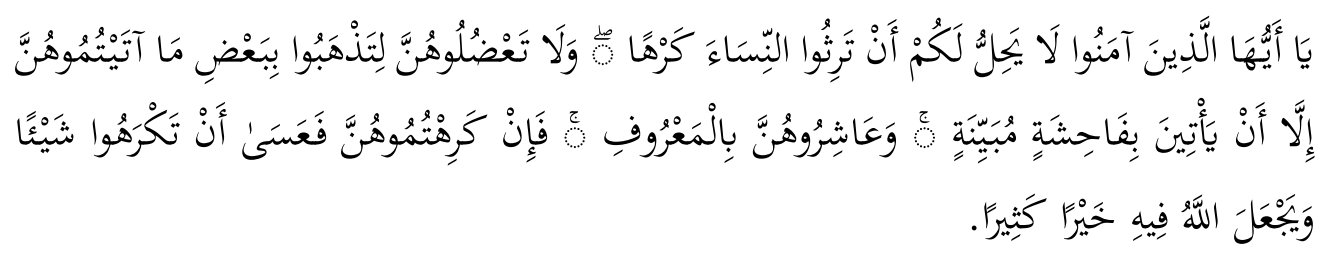

"O you who believe, it is not lanful for you to destroy women by force and do not trouble them because you want to take back some of what you have given them unless they do real beinous work. And hang out with them properly. Then if you don't like them, (then be patient) because maybe you don't like something, even though Allah made bim a lot of good".

The verse implies that the meaning of "ma'rüf" contains a good meaning, namely a term to explain goodwill and honesty of attitude towards a man carrying out his obligations as a good father and husband. This term also means forming a respectful relationship and having to keep each other's secrets. The law is forbidden to open disgrace to each other, both husband and wife.

That it is an act that is displeased with Allah and His Messenger, the Prophet said:

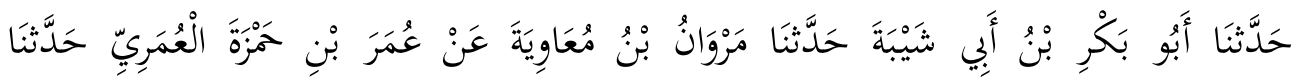

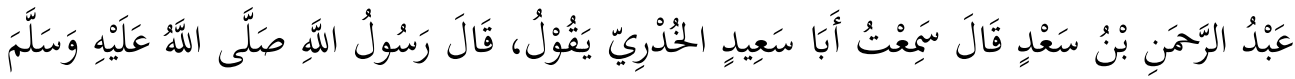

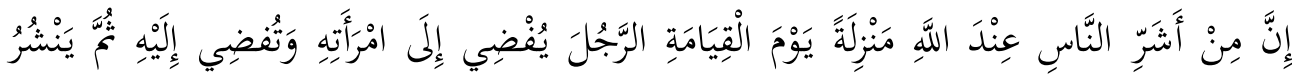

Has told us Abu Baker Ibn Abi Syaibah, has told us Marwän Ibn Mu'anwiyah from 'Umar Ibn Hamzah Al 'Amari told us Abdurrahmān bin Sa'd he said; I heard Abu Sa'id Al Khudri say; The Messenger of Allah -peace and prayer of Allah be upon bim- said: "Surely a man who has the worst position with Allah on the Day of Judgment is someone who has

${ }^{38}$ Maḥmudah 'Abd al'Āti, Keluarga Muslim, (Surabaya: Bina Ilmu, 1984), p. 223. 
intercourse with his wife and his wife has intercourse with her husband, then the husband spreads bis wife's secrets". ${ }^{39}$

The fundamental obligation and right for a life partner are to protect the honor of each partner, by not telling each other about his disgrace to others, especially a bad relationship that is so private. ${ }^{40}$

\section{Equal Obligations and Rights of Spouses}

The rights of the husband which are the obligations of the wife are obedience, respect for the husband, and create a peaceful and calm family. Obligations and rights need to be upheld to avoid a life that is full of hostility, not like in hell, but in heaven. ${ }^{41}$

Several nas which explain the equal rights and obligations of husband and wife, both in their generality and specificity. The background for the birth of the proposition of a wife's disloyalty to her husband was the cultural state of the Medina society, at which time women were more dominant than men, especially Anșär women. It could be because the Mubajirin are materially lacking. So the Prophet gave advice through his words to obey the position of the husband. ${ }^{42}$

In principle, the rights and obligations of husband and wife in the household are not different. Not a woman becomes a servant of a husband, but both as a servant of the Khālik, Allah SW'T. is what is called the principle of equality. ${ }^{43}$

\section{Position of Rights and Obligations of Husband and Wife}

During the period of ignorance, women were not valued, even as property or wealth. Babies born female were killed, because the views at that time were useless for women, bringing shame to their family and tribe or clan. ${ }^{44}$ Even the widows of people who have passed away are inheritance in themselves and can be inherited to worthy heirs (the most powerful and influential). ${ }^{45}$

${ }^{39}$ Sofware Hadis, Kitab Muslim, Wasiat untuk memperhatikan wanita, 2597.

${ }^{40}$ Sulaiman Rasyid, Fiqib Islam, (Jakarta: at-Tahiriyah, 1954), p. 365.

${ }^{41}$ Ali Yusuf as-Subki, Fiqih Keluarga Pedoman Berkeluarga dalam Islam, (Jakarta: Sinar Grafika Ofseet, 2010), p. 144.

42 Abdul Halim Abu Syuqqah, kebebasan Wanita, (Jakarta: Gema Insani, 1999), p. 136.

${ }^{43}$ Muḥammad Sa 'id Ramaụān al-Būṭī, Perrempuan Dalam Pandangan Hukum Barat dan Islam, (Yogyakarta: Suluh Press, 2005), p. 11.

${ }^{44}$ Sri suhandjati Sukri, Perempuan Menggugat Kasus dalam al Qur'ān dan Realita Masa Kini, (Semarang: Pustaka Adnan, 2005), p. 7.

${ }^{45}$ People, both nomadic and settled, live in a Bedouin tribal culture. Social organization and identity are rooted in membership in a broad community basket. Groups of several families form tribes (clans). Several tribal groups formed a tribe (tribe) led by a Shaykh. They emphasize tribal relations so strongly that group loyalty or solidarity becomes a source of strength for a tribal 
Ibn Abi Ṭalhahah, for example, quoted a narration from Ibn Abbās R.A. which explains: ${ }^{46}$

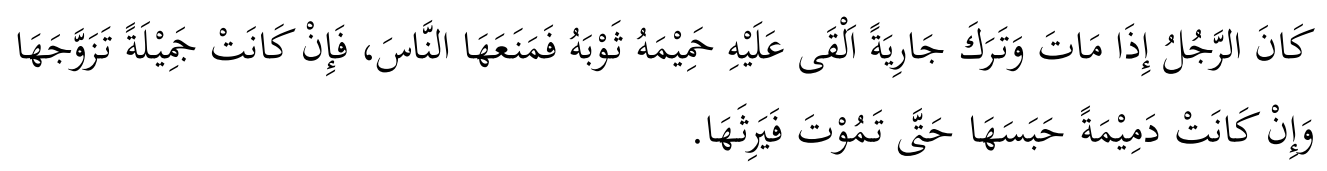

"It is said that when a man dies leaving a woman (widow), his relative throws his clothes in front of the woman. (for this act) So he forbade her to be married to someone else. If the woman is beautiful he continues to marry and if she is ugly, he will hold it until he dies, and then bis inheritance is destroyed".

It was explained that women at that time had no respect, and were considered as merchandise only. Abu Dāud narrated from 'Aisyah r.a. that there were four kinds of marriage during the era of ignorance: ${ }^{47}$

a. Spontaneous marriage. A man submits a proposal to another man who becomes a female guardian, then he can marry her after giving up the dowry immediately;

b. A man can say to his wife who is just getting clean from menstruation; "Meet Fulān and gather with him!" Her husband did not collect her and did not touch her at all until it became clear that his wife was pregnant from the person who was told to collect her. If it is clear that the pregnancy, then the husband can take his wife back if he so wishes. This is done because he wants the birth of a good and smart child. This marriage is called istib $\vec{a}$ marriage.

c. Polyandry marriages, namely marriages of several men who do not number ten people, all of whom interfere with a woman. After the woman was pregnant and gave birth to her baby, a few days later she invited all the men who were with her, and they could not refuse to gather in front of her, then she said, "You already know what has happened and now I have given birth. . This baby is your child O Fulän". He pointed to whoever he liked among them while saying his name, then the boy took the baby.

d. So many men can come to the woman he wants who is also called a prostitute woman. Usually, they put a special flag on their doorstep, as a sign for men

or tribal power. They love to fight. Because of this, tribal wars occurred frequently. This attitude seems to have become an ingrained character in the Arabs. In this warlike society, the value of women was very low. See Badri Yatim, Sejarah Peradaban Islam, (Jakarta: Raja Grafindo Persada, 1998), Cet. Ke 7, p. 9.

46 Abdul Fida' Ismail bin Katsir ad Damsyiqy, Tafsir Ibnu Katsir, Juz I, (Kairo: Darul Ihyail Kutubil 'Arabiyah), p. 465.

${ }^{47}$ Syaikh Șafiyyurraḥmān al-Mubārakfurī, Sirah Nabawiyah, (Jakarta: Pustaka al-Kautsar, 2014), Cet. Ke-8, p. 31-32. 
who want to gather. If this prostitute woman gets pregnant and gives birth to a child, she can invite all the men who've gathered her. After all, gathered, a raffle was held. Whoever is named in the lottery, then he has the right to take the child and recognize him as his child. He couldn't help it.

The tradition of inheriting his father's widow also occurred during the jahiliyah era. It is said that there was a man named Mihṣam bin Abu Qais al-Aslat. When his father passed away, he had the desire to marry his father's widow, who was not taken care of and was not given any inheritance from his father's inheritance. So that this was conveyed to the Prophet SAW. which then came down a revelation about the prohibition of marrying a widowed parent. ${ }^{48}$

After coming to Islam, Rasulullah changed beliefs and cultures that discriminated against women. The degree is equalized to that of men because they have the same degree between them. The Word of Allah in Q.S. al-Hujurāt [49]: 13:

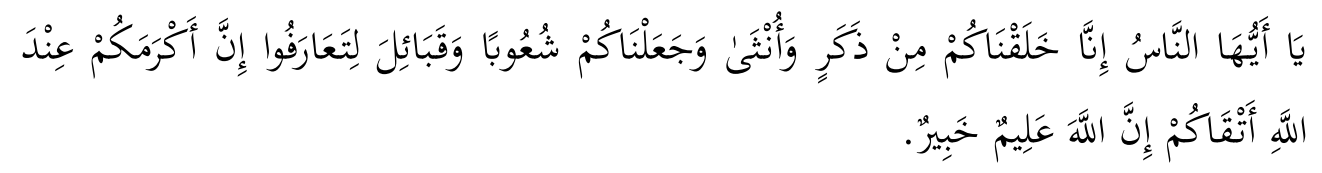

"O people, we actually created you from a man and a woman and made you nations and tribes so that you would know each other. Surely the noblest among you in the sight of Allah is the most devout among you. Allah is All-Knowing, All-Knowing"." 49

\section{Wife's Right to Husband (Husband's Obligation)}

Narrated Judge Ibn Mu'āwiyah, from his father:

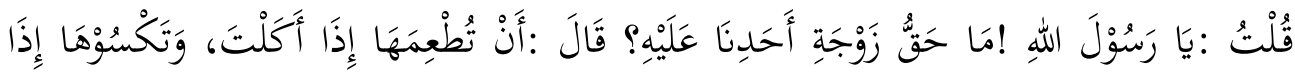

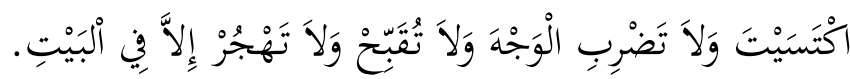

"I said, O Messenger of Allah, what is the right of the wife of one of us over her husband? He replied: You give food, when you eat, you give clothes when you dress, don't beat his face, don't badmouth bim, don't separate beds except at home".

${ }^{48}$ Q.S. an-Nisā' [4]: 19. "O you who believe, it is not lawful for you to corrupt women (widows of the dead) by force". This does not mean that it is permissible to inherit widows by means of noncoercion. (Lembaga Penterjemah Kitab Suci al-Qur'an, Juz: 1, p. 119).

${ }^{49}$ https://tafsirq.com/topik/al +hujurat+avat +13 
Narrated by Aḥmad, Abu Dāwud, an-Nasā'i, and Ibn Mājah. Bukhārī narrated mu'allaq. Authorized by Ibn Hibbān and al-Ḥākim. ${ }^{50}$ Then the rights of the wife are as follows:
a. Get a living and clothes;
b. The wife's income, according to the ability of the husband;
c. It is permissible to beat the wife (to educate her); ${ }^{51}$
d. Not getting bad treatment (such as vilifying it);
e. Get peace/security (husband is not allowed to hit the face);
f. Stay away from his wife (to taste) according to the goal, educate him. ${ }^{52}$

Besides that, a wife also has the right to have sex with her husband, just as a couple.

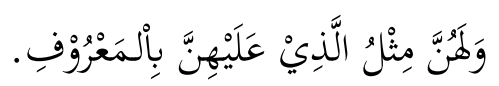

In his book, the Qurtubi ${ }^{-53}$ interprets that wives have rights similar to those of husbands, as well as the obligations that both have to do. It is because of this verse that Ibn 'Abbās once said: "I always decorate myself (look neat for my wife, just as she always adorns herself for me). Because I am very happy to accept my rights over it, then vice versa. Therefore, I will always do everything." it is my obligation for it so that my wife can do the same, namely to decorate herself with something that is not forbidden and not exaggerated". ${ }^{54}$

For women (wives) are treated with the best of friendship and relationship, as they are obliged to obey the orders of their husbands. For them to eliminate harm (something that can be dangerous). ${ }^{55}$

In Q.S. al-Baqarah [2]: 228, referred to describes the balance of rights with obligations in a ma'rüf manner. Then explained, that the husband has advantages, namely regarding his obligation to provide a living for his wife.

50 ‘Abdul Qādir Syaibah al-Hamd, Syarh Bul̄̄gu al-Maram jilid 7, terj. dari Fiqh al-Islām, Syarh Bulūgu al-Maram min Jam’i Adillati al-Aḥkām oleh Izudin karimi dkk, (Jakarta: Dārul Haq, 2012), p. 65.

${ }^{51}$ Another opinion, as stated by "Fadribūhun" means separate beds or houses.

52 Abdul Qādir Syaibah al-Hamd, Op.cit. p. 79-81.

${ }^{53}$ Died in $671 \mathrm{AH}$.

54 Abī 'Abdillāh Muhạmmad Ibn Aḥmad Ibn Abī Bakr al-Qurțubī, al-Jāmi' li Abkāmi alQur'àn wal-Mubayyin limā Tadammanubu min as-Sunnah wa Aì al-Furqān, Juz-IV (Beirut: Muassasah ar-Risālah, 2006), Cet. Ke-1, p. 51-52.

$$
{ }_{55} \text { Ibid. }
$$


Wahbah al-Zuhaily ${ }^{56}$ details some of the rights of a wife over her husband. Such as property rights in the form of "mahar" and livelihoods and rights other than property, good relations, good cooperation, and justice. What is meant by good relations is harmony and intimate relationships, avoiding damage, etc. Several things are related to the husband-wife relationship. ${ }^{57}$

a. Intimate relationship

Mälikiyah argues, "dukhüp' for wives must be performed by husbands if there is no 'age'. Syáfi'iyah said it was obligatory only once because that was the right. It is preferable not to linger, in order to avoid damage. Hanäbilah argued the husband is obliged to have sex with his wife at least once every four months if there is no obstacle. Because marriage also closes the dangers and benefits for both of them.

b. It is forbidden to fuck his wife from the back street (rectum). Those who do so are not seen by Allah on the Day of Judgment, become disbelievers, or cursed.

c. Not allowed to be in a state of menstruation or childbirth. Can make love during menstruation, but not dukhül.

d. 'Azl, namely removing sperm outside the farj. According to Imām Syāfi'î makrūh, while al-Gazālī allowed it.

e. Mu'äsyarah well, do not rule unilaterally.

f. Be fair to his wives, in the night/stay, and his living.

\section{Husband's Right to Wife (Wife's Obligation)}

In the book al-Fiqh al-Islāmī, Juz VII explains the rights of the husband. ${ }^{58}$

a. Being obedient to the wife in accepting the husband's invitation to go to bed and leaving the house;

b. Trust. Maintain the "baibab" or privacy of her husband, herself, her house, her assets, and her children;

c. Mu'äsyarah bil-ma'rüf;

d. Educating the wife in doing good, not for massiveness;

e. Bathing holy from menstruation, childbirth, and jinäbah;

f. Traveling with a wife;

Whereas in Law no. 1 of 1974, related to the rights and obligations of husband and wife are contained in Articles 30 to $34 .{ }^{59}$ Meanwhile, in the

${ }^{56}$ Died in $1436 \mathrm{AH}$.

${ }^{57}$ Wahbah az-Zuhaily, al-Figh al-Islāmi wa Adillatubu, Juz. VII: al-Aḥwäl asy-Syakbsísyyah, (Damaskus: Dārul Fikri, 1984), hlm. 327-334

${ }^{58}$ Ibid, p. 334-342.

59 R. Subekti dan R. Tjitrosudibio, Kitab Undan-Undang Hukum Acara Perdata, (Jakarta:Pradnya Paramita, 2014), p. 547-548. 
Compilation of Islamic Law (KHI Book I on Marriage), it is contained in Articles 77 to $84 .^{60}$

In essence, marriage is a contract. People who bind themselves in a contract are in a balanced position. Both parties have obligations and rights. As the husband's obligations are the wife's rights and the wife's obligations are the husband's rights. Including the issue of husband-wife intimate relations, both of them have obligations and rights, it is the husband's obligation which is the wife's right as an inner livelihood, and vice versa it is the wife's obligation which is the husband's right, as obedience.

\section{Exploring Socio-Historical}

Because of the emergence or decline of hadith (Asbäbu al-wurūd) from the said hadith, if you look at the socio-historical and cultural community, there is a possibility that it is related to the culture of abstinence from gilah. Gilah is the activity of intercourse with a wife who is breastfeeding or a pregnant woman who is breastfeeding. As said an-Nawāwī. ${ }^{61}$

Prophet Muhammad SAW. never intended to prohibit gilah, but did not, after knowing that the act did not cause harm to the children who were breastfed.

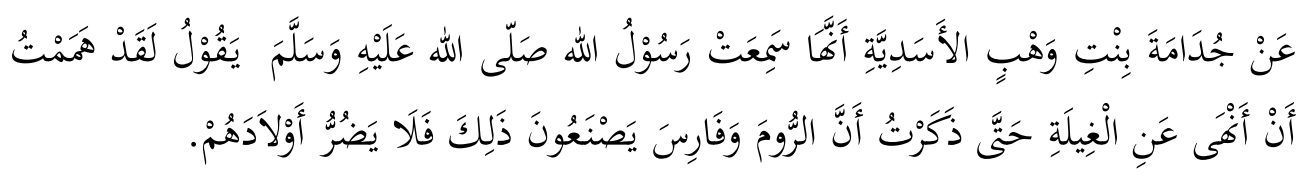

Hadith narrated by Judamah bint Wabb al-Asadiyyah R.A., That he heard Rasulullah $S A W$. said: "Verily I had intended to ban gilah but then I remembered that the Romans and Persians did this and did not harm their children". (Muslim). ${ }^{62}$

In the era of ignorance, the culture of abstinence from having sex with breastfeeding women did not have difficulties or problems. Because of that, they freely practice polygamy without limits. After Islam came, and the order of life was regulated according to sharia law, then polygamy was limited and had to be fair. If polygamy has restrictions, while gilah is still prohibited, it will be burdensome for the Arab community, especially Adam. It could be that the background of this hadith was a solution for the Arab community at that time, as

${ }^{60}$ Abdurrahman, Kompilasi Hukum Islam di Indonesia, (Jakarta: Akademika Pressindo, 2018), p. $132-134$.

${ }^{61}$ Sinta Nuriah, dkk, Loc. Cit, p. 50.

62 Abu Husain Muslim Ibn Husain Ibn al-Hajjaj an-Naisyābūrī, (Wafat 261 H.), Sahīh Muslim, Jilid. I, (Kairo: Dār al-Hadīs, 1991), p. 232. 
well as eliminating taboo to carry out gilah, especially for women who still adhere to it.

As a medical review, going into bed ( $\ddot{i m a ̄}$ ) during pregnancy has many positive effects on pregnant women. Pregnant women will experience an increase in sex drive in the second trimester. When the energy level starts to increase as nausea gets less and less. Sex can be the number one thing pregnant women think about at this time because there is an increase in blood flow to the vagina, so the vagina gets bigger and experiences increased lubrication (lubricating fluid). The desire for women to have sex during pregnancy increases and orgasms can be even greater than usual. In addition, physical changes in the form of increasing body weight and an increasingly enlarged stomach will make it less difficult to experience sexual intercourse. The baby in the mother's womb is protected by a very strong uterine wall. ${ }^{63}$

Quoted from "halodoc", 64 the benefits of being intimate with a pregnant wife contain several benefits; (1) improve blood circulation, (2) strengthen the pelvic floor muscles, (3) increase the body's immune system, (4) lower blood pressure, (5) accelerate post-birth recovery, (6) make childbirth easier.

On the other hand, the reason for this hadith was that it was probably related to the marriage of Anșār and Mubajirin after moving to Medina. At that time, the Mubajirin who participated in the bijrab did not bring sufficient provisions/assets, while the native Medina women (Anșār) had more wealth than the men who came to migrate. Sociologically and psychologically, many of the Medina women felt that their social strata were higher. So when they get married sometimes there is still a sense of superiority and it has an impact on sexual relations. This could happen if were allowed, the harmony and happiness of the family will be disturbed.

\section{Scientific Review (Health) and Hadith Relevance}

From a medical point of view, it can be understood that the benefits of intimate relationships are to strengthen bonds between two people and foster closeness, love, and affection between partners. In addition, it also helps overcome the differences between the two. Oxytocin, a hormone, and neurotransmitter released during intimate moments between partners increases trust and a stronger sense of friendship. It does not just have fun in bed, but also brings health benefits, including; ${ }^{65}$ (1) Helps maintain the immune system, (2)

${ }^{63}$ Muhammad Ikhwan Lukmanudin, Jurnal Tahkim, Vol. XIII, No. 2, Desember 2017, p. 88.

${ }^{64}$ https://www.halodoc.com/7-manfaat-melakukan-hubungan-intim-saat-hamil accessed on Saturday, 26 April 2020, at 09.35 WIB.

65 https://www.halodoc.com/inilah-7-manfaat-hubungan-intim-untuk-kesehatan, accessed at 9:25, Wednesday, April 22, 2020. 
Reduces stress, (3) Burns calories (4) Increases libido, (5) Improves bladder control, (6) Lower blood pressure, (7) Look younger, (8) ) Improved sleep quality and (9) Long life.

Imām al-Gazālī, ${ }^{66}$ explains the relationship between husband and wife:

"You know, actually sexual relations carried out by humans have two purposes, namely:

(1) so that he can get delicious (great pleasure) sex, which deliciously be will be aroused to get a bigger delicious tomorrow in the hereafter (beaven. ). (2) In order to have offspring (children) to preserve buman life on earth". ${ }^{67}$

In particular, there are reference books for bed problems in order to maintain harmony. For example, Qurrah al-'Uyün fì an-Nikäh asy-Syar'i have written by Abu Muhammad at-Tihāmīi. ${ }^{68}$ This 66-page book discusses jima', starting with the law of marriage, its virtues, and its benefits. The next chapter, adäb al-jimm $\bar{a}^{\prime}$, is concerned with the time and procedure of intercourse, the do's and don'ts to do before, during, and after intercourse, and models of intercourse. In addition, this book also dares to show women erotic places that can help achieve sexual satisfaction for both partners.

There are other books, such as "Sexuality in Islam" that explain the relationship between husband and wife using a socio-historical approach. ${ }^{69} \mathrm{In}$ addition, there is also a book entitled "Ethics Jima" "Explaining ethics, positions, and variations of jima' in Islamic perspective. ${ }^{70}$ In essence, some of the books and studies are aimed at married couples. The problem is, what if the wife refuses the husband's invitation that is eager? Psychologists argue that male sexual desire is stronger related to his physiological function. When the desire increases, the male collects sperm, demanding that it be channeled immediately. This is different from women, depending more on the psychological need to get warmth and flirting from the partner he loves. ${ }^{71}$

${ }^{66}$ Died in $505 \mathrm{AH}$.

${ }^{67}$ Abu Ḥāmid Muḥammad Ibnu Muḥammad al-Gazālī, Ihyà 'Ulūmu ad-Dìn, Juz III, (Beirut: Dār al-Ma'rifah, t.t.), p. 99.

68 Abu Muḥammad at-Tihāmī, Qurrah al- 'Uyūn fì an-Nikeāh asy-Syar'i, (Kediri: al-Ma’had alIslāmī as-Salafì, t.t), See also in Indonesian: Muhammad at-Tihāmī, Qurrah al- 'Uyūn: bi Syarbi Nažmi Ibnu Yamūn, Translation: A. Ma'ruf Asrori, (Jakarta: Bintang Terang, 2006).

${ }^{69}$ Abdel Wahab Bouhdiba, Sexsuality in Islam; Peradaban Kelamin Abad Pertengahan, Alih Bahasa: Ratna Maharani Utami, (Yogyakarta: Alenia, 2004).

${ }^{70}$ M. Syamsi Hasan dan A. Ma'ruf Asrori, Etika Jima': Posisi dan Variasinya, (Surabaya: alMiftah, 1998).

${ }^{71}$ Muhammad Fauzil Adhim, Mencapai Pernikahan Barokah, (Yogyakarta: Mitra Pustaka, 1999), p. 181-182. 
The theoretical scientific study concluded that intimate relationships can make a man feel love and he really needs it. As for Eve, it's the opposite. He is more likely to feel needy and miss sexual relations when he has found romance. For women, the key is that love can bring her to feel the need and desire to have sex. ${ }^{72}$ The fact is that there are also sexual differences between men and women $;{ }^{73}$ (1) There is a change in female sexual desire because of the monthly cycle (menstruation) and physical hormonal changes. While men are passionate about every time they explode and don't know the time. (2) Men are easily aroused, even if they only think about or fantasize about sexual activity, without foreplay. Meanwhile, for women, there needs to be warming up first, not to the point as usual for men.

The number of arguments about emphasizing the husband's rights in prolonged relationships and encouraging wives to fulfill them immediately is the nature of men to sue, while women are the ones being sued. So there needs to be a balance when asking (gently), while the respondent should also be affectionate and gentle in fulfilling the husband's call.

\section{The Law of Husbands Refusing to Wives with Marriage}

Health experts see, that jima' as a factor for maintaining health. According to Galenos, semen is controlled by the elements of fire and air, a mixture of heat and humidity, because it is formed from pure blood which becomes the basic organ food. If there is excess semen, it must be removed to have offspring. If semen accumulates, it can cause various diseases. ${ }^{74}$

However, the hadith editorial who gets cursed is the wife if she does not fulfill the husband's request. Then what if the husband refuses to comply if the wife asks first? Are you cursed too?. When referring to Q.S. al-Baqarah [2]: 228; "And wives have the same rights/equal to their obligations according to the ma'ruf way". So husband and wife have the same rights, including requests for intimate relationships. If a good wife asks, then the husband refuses to apply the cursing law.

This is also reinforced by the history of 'Aun Ibn Juhaifah from his father who tells about Umm Darda who complained about her husband who no longer needed her when asked by Salmān al-Fārisi. Salmān also advised Abu Darda: "Verily, your Rabb has rights over you, yourself also has rights over you, and your wife has rights over you. So, give every right to the owner "Abu Darda then asked

72 Thariq kamal an-Nu'aimi, Kado Pernikahan: Psikologi Suami Istri. Edisi Terjemah, (Yogyakarta: Mitra Pustaka, 2000), p. 588.

${ }^{73}$ Muhammad Fauzil Adhim, Op. Cit, p. 183.

${ }^{74}$ Ibnu Qayyim Al-Jauziyyah, Original title: MukhtaȘar Zādul Ma’ad, (Dār al-Fikr: 1990), translation book, Kathur Suhardi, Zädul Ma’ad Bekal Menuju ke Akherat, Jakarta: Pustaka Azzam, 2000), p. 317. 
Rasulullah SAW. and he said: "Salmān is right". ${ }^{75}$ There are several other traditions that mention the rights of the wife, which when she demands to have intercourse, her husband must fulfill it.

Why is Angel's threat aimed only at women, not at men? There are considerations that can be put forward;

1. Men are usually more aggressive in inviting, while women are sought after to hang out with. It is true, that the husband invites/asks his wife to serve him, on the other hand, if a wife asks her husband to have sex, it is rare for a normal husband to refuse, because that is what the husband expects;

2. Likewise, if a woman does not desire to have sex, she can still serve her husband, in contrast to a man, if she does not desire, then his genitals cannot become erect and cannot serve his wife;

3. The patience of a man not to have sex is very weak compared to the patience of a woman not to have sex;

4. Men are also moved faster than women.

\section{Conclusion}

The purpose of marriage is worship, completing half of the religion. "I $\dot{z} \bar{a}$ tazawwaja al-'abdu faqad istakmala nișfa ad-din fal yattaqillāha fi nișfi al-bāqi". "When a servant gets married, it means he has completed half of his religion. So fear the remaining half". One of the strengths of the relationship between husband and wife is the quality of the sexual relationship. The more quality the sexuality is, the more it will strengthen the household ark.

In marriage, the curse of angels can occur to husbands and wives if they are reluctant to have sex. In terms of equality, intimate relationships are the husband's obligation to fulfill his wife's physical and spiritual needs, while for the wife it is an obligation as a form of obedience. From the socio-historical point of view, why was this hadith revealed, to remind women (Medina) of being reluctant to accept their husband's invitation to have sex. They felt that their social strata were higher, because the emigrants at that time lacked wealth. So, if the invitation is asked with kindness, gentle, both husband to his wife or vice versa, then reluctant, then the curse of the Angel will descend for those who are reluctant. When viewed from a health perspective, why is this hadith only addressed to women? Because men have instincts in bed relationships are more aggressive, and

\footnotetext{
al-Syāmilah).

${ }^{75}$ Maktabah asy-Syāmilah, Min Aqsama 'alā Akbỉhi li Yaftura fì al-Tatawnu', (al- Maktabah
} 
take the initiative to invite. While women have shy traits, in addition to the monthly cycle of hormonal changes (menstruation).

The obedience of the wife is the key to happiness (sa'adab), the responsibility of the husband is perfection. When husband and wife carry out their respective obligations, sakinah, mawaddah wa rahmah will be achieved. The more the husband completes his wife's shortcomings, and vice versa, the closer to heaven. "Hunna libāsun lakum, wa antum libāsun lahun". "You are clothes for them, so they are clothes for you".

\section{Bibliografi}

'Abd al'Āti, Mạ̣mudah, Keluarga Muslim, (Surabaya: Bina Ilmu, 1984).

Abdirraḥmān, Abu, 'Aun al-Ma'būd 'alà Syarh Sunan Abì Dāwud, (Beirut: Dār Ibnu Hazm, 2005).

Abdurrahman, Kompilasi Hukum Islam di Indonesia, (Jakarta: Akademika Pressindo, 2018).

Abu 'Abdul Mu’țī Muhammad Ibn 'Umar Ibn Arbi Ibn 'Alī al-Tanara Al-Jāwi AlBantan̄̄, Syarhu 'Uqūdu al-Lujjaini fì Bayāni Huqūq až-Zaujaini, (bil-Ma'nā 'alā Pesantren), (t.p. t.t.).

Abu Ḥusain Muslim Ibn Ḥusain Ibn al-Hajjāj an-Naisyābūrī, (Wafat 261 H.), Șahịh Muslìm, Jilid. I, (Kairo: Dār al-Hadīis, 1991).

Abu Syuqqah, Abdul Halim, kebebasan Wanita, (Jakarta: Gema Insani, 1999).

Adhim, Muhammad Fauzil, Mencapai Pernikahan Barokah, (Yogyakarta: Mitra Pustaka, 1999).

Al-Qurțubī, Abī 'Abdillah Muḥammad Ibn Aḥmad Ibn Abī Bakr, al-Jāmi' li Ahkeàmi al-Qur'ān wal-Mubayyin Limā Tadammanubu min as-Sunnab wa Aiy alFurqān, Juz-IV (Beirut: Muassasah ar-Risālah, 2006).

-------------, al-Jāmi’u li Abkèm al-Qur'ān, Juz XIV. (Kairo: Dār al-Kātib al-'Arabī, 1967).

Al-'Asqalānī, Al-Hāfị Ahmad Ibn 'Alī Ibn Ḥajar (773-852 H.), Bulūgu al-Maram min Adillati al-Abkām: Kitāb an-Nikēh, (Makkah: Dāru al-Qabbas, 2014), Cet. Ke-1.

--------, Fath al-Bārì bi Syarh Șahịh al-Bukhārì, editor al-'Azīs Ibn 'Abdullāh Ibn Bāz and Muḥammad Fu'ād 'Abd. al-Bāqī, juz 25 (Jakarta: Pustaka Azzam, 2008).

---------, Fathu al-Bäri, Jilid 25, (Jakarta: Pustaka Azzam, 2007).

Al-Bukhārī, Abī 'Abdillāh Muḥammad Ibn Ismā’īl (194-256 H.), Șahỉhu al-Bukbārì, Kitāb an-Nikeāh, Hadith no. 5193, (Damsyīq Beirut: Dāru Ibnu Kasīir, 2002).

Al-Būthi, Muḥammad Sā'id Ramadān, Perempuan Dalam Pandangan Hukum Barat dan Islam, (Yogyakarta: Suluh Press, 2005). 
Al-Gazālī, Abu Ḥāmid Muḥammad Ibn Muḥammad, Ibyà Ulūm ad-Dìn, Juz III, (Beirut: Dār al-Ma’rifah, t.t.).

Al-Ḥamd, 'Abdul Qādir Syaibah, Syarh Bulügu al-Maram Vol. 7, Translate from Fiqh al-Islām, Syarh Bulūgu al-Maram min Jam’i Adillati al-Ahkām by Izudin karimi et al, (Jakarta: Dārul Haq, 2012).

Al-Jauziyyah, Ibnu Qayyim, The Origina Title: Mukhtașar Zādul Ma'äd, (Dār alFikr: 1990), Translation Book, Kathur Suhardi, Zādul Ma'àd Bekal Menuju ke Akherat, (Jakarta: Pustaka Azzam, 2000).

Al-Jaziri, 'Abdurraḥmān, al-Fiqh 'alà Mażāhib al-Arba'ah, (Beirut: Dār al-Fikr, 1986), Volume IV.

Al-Mubārakfuri, Syaikh Șafiyyurraḥmān, Sirah Nabawiyah, (Jakarta: Pustaka alKautsar, 2014), Mold to 8.

An-Nawāwī, Maḥyuddīn Abī Zakariyā Yaḥyā Ibn Syaraf, Rìyādu aṣ-Ṣälibìn min Kalāmi Sayyidi al-Mursalīn, (Jakarta: Dār Ihyāi al-Kutub al-'Arabiyyah Indonesia, t.t.).

An-Nu'aimi, Thariq Kamal, Kado Pernikahan: Psikologi Suami Istri. Translated Edition, (Yogyakarta: Mitra Pustaka, 2000).

As-Subki, Ali Yusuf, Fiqih Keluarga Pedoman Berkeluarga dalam Islam, (Jakarta: Sinar Grafika Ofseet, 2010).

At-Tihāmī, Abu Muhammad, Qurrah al-Uyūn fì an-Nikāh asy-Syar'i, (Kediri: alMa'had al-Islāmī as-Salafì, t.t.).

-------, Qurrah al-Uyün: bi Syarbi Nažmi Ibnu Yamün, Translation: A. Ma'ruf Asrori, (Jakarta: Bintang Terang, 2006).

Az-Zuhaily, Wahbah, al-Fiqh al-Islāmì wa Adillatubu, Juz. VII: al-Ahwäl asySyakhsizyah, (Damaskus: Dārul Fikri, 1984).

Bouhdiba, Abdel Wahab, Sexsuality in Islam; Peradaban Kelamin Abad Pertengahan, Translation: Ratna Maharani Utami, (Yogyakarta: Alenia, 2004).

Direktorat Pembinaan Peradilan Agama Islam Ditjen Pembinaan Kelembagaan Islam Departemen Agama, 2001.

Hakim, Rahmat, Hukum Perkawinan Islam, (Bandung: Pustaka Setia, 2000), Mold to III.

Hasan, M. Syamsi and Asrori, A. Ma'ruf, Etika Jima': Posisi dan Variasinya, (Surabaya: al-Miftah, 1998).

Kas̀īr ad Damsyīqy, 'Abdul Fidā’ Ismā ‘̄il Ibn, Tafsīr Ibnu Kàìre, Juz I, (Cairo: Dārul Ihyā'il Kutubil 'Arabiyah).

Maktabah asy-Syāmilah, Min Aqsama 'Alā Akbỉhi li Yaftura fì al-Tațawnu', (alMaktabah al-Syāmilah).

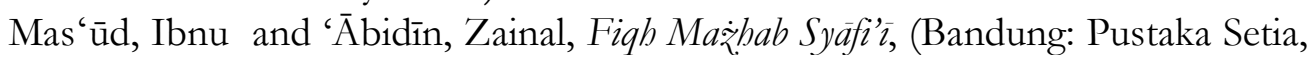
2007). 
692 AL QUDS : Jurnal Studi Alquran dan Hadis vol. 5, no 2, 2021

Mayai, As-Sayyid, 50 Wasiat Rasulullab SAW Bagi Wanita, (Jakarta: Pustaka alKautsar, 1999).

Mukhtar, Kamal, Asas-Asas Hukum Islam tentang Perkawinan, (Jakarta: Bulan Bintang, 1993), Mold to III.

Muṣțafā al-Iskandarī, Muḥammad Ibn Muḥammad, Masā’il fì az-Zawāj wa al-ḥaml wa al-Wilādah, (Beirut: Dār Ibnu Hazm, 2002).

Nipan, Muhammad Abdullah, Membahagiakan Suami Sejak Malam Pertama, (Yogyakarta: Mitra Pustaka, 2000).

Nuriah, Sinta, et al, Wajah Baru Relasi Suami Istri Telaah Kitāb Uqūd al-Lujjaìn, (Yogyakarta: LKIS Press, 2001).

Ramulyo, Moh. Idris, Hukum perkawinan Islam, (Jakarta: Sinar Grafika Offset, 1999).

Rasavena, Atania, Seni Bercinta, Pnduan Bercinta ala Melayu Islam, (Yogyakarta: Sophiebooks, 2003).

Rasyid, Sulaiman, Fiqih Islam, (Jakarta: aț-Ṭāhiriyah, 1954).

Saebani, Beni Aḥmad, Fiqh Munākahāt 2, (Bandung: CV Pustaka Setia, 2010).

Sofware Hadis, Kitab Muslim, Wasiat untuk memperhatikan wanita, 2597.

Subekti, R. dan Tjitrosudibio, R., Kitab Undan-Undang Hukum Acara Perdata, (Jakarta:Pradnya Paramita, 2014).

Sukri, Sri Suhandjati, Perempuan Menggugat Kasus dalam al Qur'ān dan Realita Masa Kini, (Semarang: Pustaka Adnan, 2005).

Syarifuddin, Amir, Hukum Perkawinan Islam di Indonesia, (Jakarta: Prenada Media, 2007).

Syarifuddin, Amir, Hukum Perkawinan Islam di Indonesia: Antara Fiqh Munäkahāt dan Undang-undang Perkawinan, (Jakarta: Kencana, 2006).

Munawwir, Ahmad Warson, Kamus Al-Munawwir, (Surabaya: Pustaka Progressif, 1997)

Yatim, Badri, Sejarah Peradaban Islam, (Jakarta: Raja Grafindo Persada, 1998), Mold to 7 .

https://www.halodoc.com/7-manfaat-melakukan-hubungan-intim-saat-hamil accessed Saturday, April 26, 2020, at 09.35 WIB (AM).

https://www.halodoc.com/inilah-7-manfaat-hubungan-intim-untuk-kesehatan, accessed at 9:25, Wednesday, 22 April 2020 WIB (AM).

theconversation.com/larangan-islam-atas-pemerkosaan-dalam-perkawinan79232

Khatimah, Umi Khusnul, Hubungan Seksual Suami Istri Dalam Perspektif Gender dan bukum Islam, Jurnal Ahkam: Vol. XII, No. 2, juli 2013.

Kompilasi Hukum Islam (Islamic Law Compilation), Book I Marriage Law.

Lukmanudin, Muhammad Ikhwan, Jurnal Tahkim, Vol. XIII, No. 2, Desember 2017.

Tim Penyusun MKD IAIN Sunan Ampel Surabaya, Studi Hadis, (Surabaya: IAIN Sunan Ampel, 2012).

UU. R.I. Nomor 1 Tahun 1974, About Marriage. 